Solomou, D.A., Skoufogianni, E., Giannoulis, D. K., Charvalas, G., Danalatos, G. N. (2020): Effects of environmental factors on herbaceous plant diversity in an organic cultivation of sage (Salvia officinalis L.) in a typical Mediterranean climate. Agriculture and Forestry, 66 (2): 7-17.

DOI: 10.17707/AgricultForest.66.2.01

Alexandra D. SOLOMOU ${ }^{*}$, Elpiniki SKOUFOGIANNI', Kyriakos D. GIANNOULIS ${ }^{2}$, George CHARVALAS ${ }^{2}$, Nicholaos G. DANALATOS ${ }^{2}$

\title{
EFFECTS OF ENVIRONMENTAL FACTORS ON HERBACEOUS PLANT DIVERSITY IN AN ORGANIC CULTIVATION OF SAGE (SALVIA OFFICINALIS L.) IN A TYPICAL MEDITERRANEAN CLIMATE
}

\section{SUMMARY}

Sage (Salvia officinalis L.) is a perennial aromatic-medicinal plant that is commonly cultivated for pharmaceutical uses through the Mediterranean basin. The purpose of this study was to examine the herbaceous plant diversity (plant species richness), composition and their utilization as well as the relationships between herbaceous plant species richness and driving factors (e.g. soil $\mathrm{pH}$, organic matter, temperature, minerals etc) in the organic cultivation of Sage in central Greece. The results showed that the most frequently occurring species were: Papaver rhoeas L., Chenopodium album L., Fumaria officinalis L. and Urtica dioica L. Our data suggested that these plants constitute important soil indicators which could be used to monitor the state of soils along with assessing the role of soil in environmental interactions. According to Principal Component Analysis (PCA), herbaceous plant species richness was positively correlated to soil organic matter, temperature and moisture, $\mathrm{P}$ and $\mathrm{K}$ in the organic cultivation of Sage. The results of this study highlight the ecological value of the organic sage cultivation and how it can be a useful tool for the ecosystem's environmental protection, the wider scientific community and the general public during the current economic crisis.

Keywords: aromatic plants; environment; Greece; sage; utilization.

\section{INTRODUCTION}

It is a well-known fact that Greece has a vast plant biodiversity, amongst the highest in Europe and the Mediterranean region. Greece counts 5828 species

\footnotetext{
${ }^{1}$ Alexandra D. Solomou (corresponding author: alexansolomou@gmail.com), Institute of Mediterranean and Forest Ecosystems, Hellenic Agricultural Organization "DEMETER", N. Chlorou 1, Ilisia, 11528, Athens, GREECE.

${ }^{2}$ Elpiniki Skoufogianni, Kyriakos D. Giannoulis, George Charvalas, Nicholaos G. Danalatos, Department of Agriculture, Crop Production and Rural Environment, University of Thessaly, Fytokou Str., 38446, N. Ionia, Magnesia, Volos, GREECE.

Paper presented at the GEA (Geo Eco-Eco Agro) International Conference 2020, Podgorica Notes: The authors declare that they have no conflicts of interest. Authorship Form signed online. 
and 1982 subspecies (either native or naturalized) which consequently represent 6695 taxa belonging to 1083 genera and 185 families. Therefore, that's the reason why Greece is considered to be a very important spot of endemism in Europe and the Mediterranean basin (Dimopoulos et al., 2013; 2016). A very important fact is the existence of aromatic medicinal plants having renowned pharmaceutical values (Solomou et al., 2017). In fact, there are 1683 species and subspecies which represent $25 \%$ of the Greek flora. Greek microclimatic conditions together with the country's topography are ideal for the development and progress of aromatic and medicinal plants (Bogers et al., 2006; Solomou et al., 2016).

Recent studies have underlined the importance of these plants in the fields of environmental protection, sustainable development and of course, public health. Their use has been widely known since antiquity and their pharmaceutical, cosmetic and culinary values are currently being acclaimed once more. In the mid-nineties there was a serious decline concerning the cultivation of these plants but over the last few years their properties are the subject of extensive research. Fortunately, at present, there is a tendency to "re-discover" their importance and capitalize on their cultivation. Species such as Dictamus (Origanum dictamus), Oregano (Origanum vulgare) (Skoufogianni et al., 2019), Mountain Tea (Sideritis sp.) (Solomou et al., 2019), Chamomile (Chamomilla sp.), Aloysia (Lippia citriodora) (Solomou et al., 2020) and Sage (Salvia officinalis) are nowadays being cultivated- while it must be noted that especially sage cultivation is on the increase (Stefanou et al., 2015; Skoufogianni et al., 2017).

Sage belongs to the Lamiaceae family which includes nearly 900 species. Being rich in essential oils, phenolic compounds and vitamins, sage is one of the stars of medicinal plants. Its properties are highly ranked ranging from antibacterial/antiviral to anti-inflamatory, antidiabetic and even anti-tumor (Christopoulou-Geoyiannaki and Masouras, 2015). A high quality raw material can be provided by organic cultivation which also boosts the crop diversity an important element concerning organic farming (Verma et al., 2017). Sage has recently been the subject of several studies (Bradley, 2006; Russo et al., 2013; Russo et al., 2015; Ravlic et al., 2016). However, there is still a lack of available data which would specify the utilization, dynamics and environmental determinants of its diversity in organic cultivation. The role of herbaceous plants in the ecosystem is paramount and they should be further studied.

Hence, the objectives of this research were to determine: a) the richness and composition of herbaceous plant species, b) the plant species utilization and c) the correlation of the species richness with specific environmental factors (e.g. soil $\mathrm{pH}$, organic matter, temperature, minerals etc) in the organic cultivation of Sage.

Study area

\section{MATERIAL AND METHODS}

The study was conducted in a Thessaly plain (Velestino, central Greece) (Fig.1). The climate of the area is characterized as typical Mediterranean and 
continental with hot and dry summer followed by a humid and cool winter. The soil characterized as clay loam with high amount of calcium and good drainage (Mitsios et al., 2000).

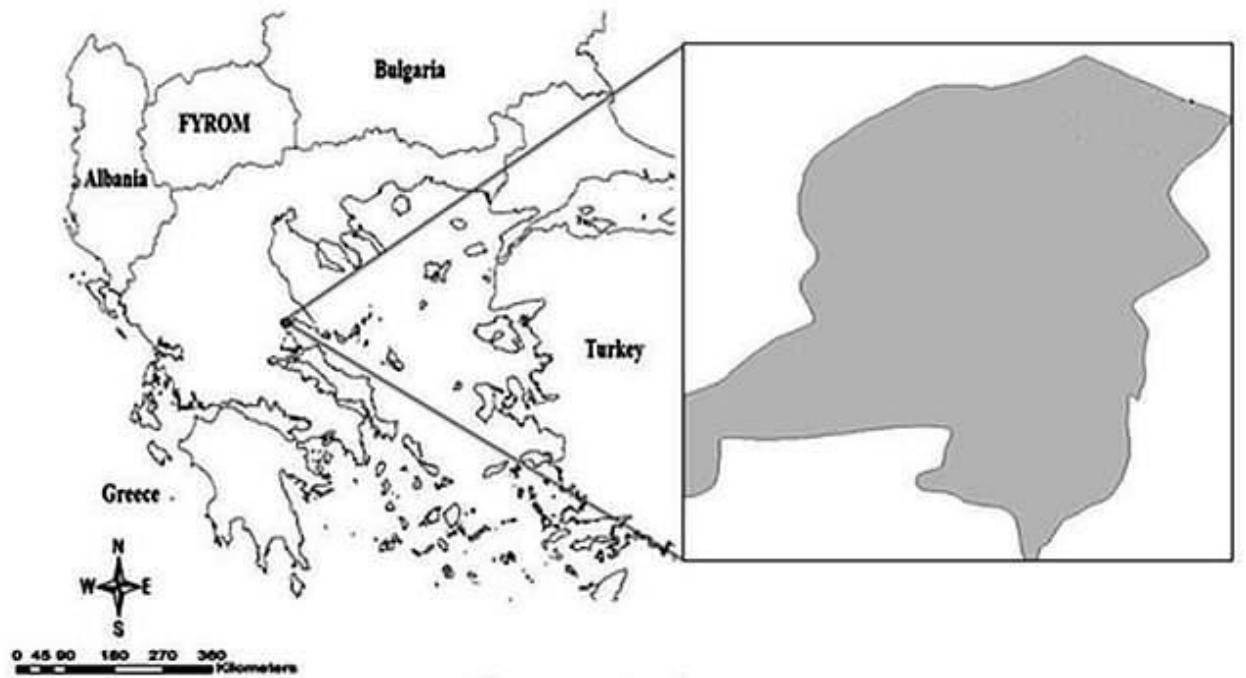

Figure 1. Study area

\section{Sampling}

The sampling of herbaceous plant communities was done in organic cultivation of sage in the experimental fields of University of Thessaly in central Greece during the spring of 2016, 2017 and 2018. The samplings of herbaceous plants were carried out in plots $0.25 \mathrm{~m}^{2}(0.5 \mathrm{~m} \times 0.5 \mathrm{~m})$, in order to record herbaceous plant diversity (plant species richness) and composition (Cook and Stubbendieck, 1986; Solomou and Skoufogianni, 2016).

In each plot composite soil samples were taken by the randomized method (soil depth: 0-40 cm). Soil organic matter (\%) (Nelson and Sommers, 1982), pH (McLean, 1982), phosphorus (P) (Olsen and Sommers, 1982), potassium (K) (Thomas, 1982) and nitrogen (N) (Bremner and Mulvaney, 1982) were measured. Also, soil temperature (soil Digital Thermometer-TFA) and moisture (Page et al., 1982), air humidity and temperature (Digital Thermo-Hygrometer, TFA) were recorded.

Data were evaluated for normality and homogeneity of variances with the Kolmogorov-Smirnov and Bartlett's tests (Zar, 1999). Also, Principal Component Analysis (PCA) was carried out to determine the strength of the relationships between herbaceous plant species richness (one of several diversity indices used to measure diversity) and environmental factors (e.g. soil $\mathrm{pH}$, organic matter, phosphorus $(\mathrm{P})$, potassium $(\mathrm{K})$, nitrogen $(\mathrm{N})$, temperature and moisture, air humidity and temperature) in an organic cultivation of sage.

All statistical analyses were performed using the software package IBM SPSS Statistics ver. 23.0 for Windows (IBM 2015) and the ordination software CANOCO (Ter Braak and Smilauer, 2002). 


\section{RESULTS AND DISCUSSION \\ Herbaceous plant communities, composition and utilization}

The study recorded 36 herbaceous plant species richness which belong to 15 families (Table 1) in the organic cultivation of sage. The most frequently occurring species were: Chenopodium album L. (16\%) (Family: Chenopodiaceae), Papaver rhoeas L. (15\%) (Family: Papaveraceae), Fumaria officinalis L. (12\%) (Family: Fumariaceae) and Urtica dioica L. (11\%) (Family: Urticaceae). The study recorded 36 herbaceous plant species richness belonging to 15 families (Table 1) in the organic cultivation of sage. Frequently occurring species were: Chenopodium album L. (16\%) (Family: Chenopodiaceae), Papaver rhoeas L. (15\%) (Family: Papaveraceae), Fumaria officinalis L. (12\%) (Family: Fumariaceae) and Urtica dioica L. (11\%) (Family: Urticaceae). Agroecosystems support a large number of plant species and are considered high nature-valued farming systems, enhancing/promoting biodiversity.

According to literature (Bengtsson and Weibull, 2005) organic agriculture is a farming system which promotes ecosystem protection and its produce is free from substances such as chemicals and pesticides. Tuamisto et al. (2012) reported the positive environmental effects of organic farming, not to mention its contribution to diversity and soil quality. As an example of the increase regarding diversity we have vascular plants (Hyvönen and Salonen, 2002) and a general total (Ahnström, 2002; Bengtsson and Weibull, 2005). We should also note that the composition and the diversity of native flora are influenced by factors such as (a) agricultural practices, (b) landscape structure, (c) current crops, (d) crop size, (e) herbivores which may affect (Fischer et al., 2011) and f) age, an important factor explaining about $8-10 \%$ of the change in the composition and diversity of the flora (Cordeau et al., 2010).

Dimopoulos et al. (2013) report in their study that the above plant species that were recorded in the organic cultivation of sage are characteristics of rural ecosystems and could contribute significantly to their protection. It is important to mention that the above most frequently occurring plant species constitute important indicators of the state, productivity and the health of the soil (Chenopodium album: indicator of good nutritional status of the soil), Papaver rhoeas (indicator of non-acid soil), Fumaria officinalis (indicator of ventilated and wet soils) and Urtica dioica (indicator of soil nitrogen). Also, these plants have medicinal uses which could be utilized and described below:

Hence, Chenopodium album is an indicator of the soil's good nutritional status, Papaver rhoeas indicates a non-acidic soil, Fumaria officinalis reflects a well ventilated and wet soil and lastly, Urtica dioica signals the soil's nitrogen. Furthermore, we should also mention the medicinal uses of these plants. More specifically:

- Chenopodium album presents antirheumatic and anti-inflammatory properties. The leaves can be used not only as an infusion but also as a poultice on bug bites/ sore areas of the body (http1). 
- Papaver rhoeas and its flowers have useful properties tackling mild pains and stress. In contrast to the related opium poppy, there is no danger of addiction but should be used under supervision/ advice from an herbalist. The flowers of the plant are dried and concocted and the syrup is used in small quantities inducing sleep, while the leaves and seeds are used for opposing results, that of a tonic. Another latest finding regarding the plant's properties has to do with antitumor effects (http2).

- Fumaria officinalis has been known since Roman times. It can be administered either externally or internally for the treatment of inflammations and skin conditions. Its harvest takes place in summer when the plant blooms. However, excessive doses may cause unwanted hypnotic effect so there must be caution and expert advice (http3).

- Urtica dioica is a very valuable medicinal plant. Its infusion combats anemia, asthma attacks and even arthritis and rheumatism. Its nettles on the skin cause hyperaemia proven beneficilal to arthritic/rheumatic joints. The leaves can be best harvested during May-early June and dried for further use (http4).

Table 1. Herbaceous plant species in sage cultivation

\begin{tabular}{|c|c|c|c|c|c|}
\hline FAMILY & PLANT SPECIES & $\begin{array}{c}\text { FREQUENCY OF } \\
\text { OCCURRENCE } \\
(\%)\end{array}$ & $\begin{array}{l}\text { MEDICINAL } \\
\text { PLANT }\end{array}$ & $\mathbf{C H}^{*}$ & $\mathbf{L F}^{* *}$ \\
\hline Amaranthaceae & Amaranthus albus L. & 2 & & $\begin{array}{l}{[\mathrm{N}-} \\
\mathrm{Am} .]\end{array}$ & $\mathrm{T}$ \\
\hline Amaranthaceae & $\begin{array}{l}\text { Amaranthus } \\
\text { retroflexus L. }\end{array}$ & 2 & & $\begin{array}{l}{[\mathrm{N}-} \\
\mathrm{Am} .]\end{array}$ & $\mathrm{T}$ \\
\hline Asteraceae & Arctium lappa $\mathrm{L}$. & 1 & Yes & ES & $\mathrm{H}$ \\
\hline Asteraceae & Beilis perennis $\mathrm{L}$. & 1 & Yes & EA & $\mathrm{H}$ \\
\hline Boraginaceae & $\begin{array}{l}\text { Heliotropium } \\
\text { europaeum L. }\end{array}$ & 1 & Yes & ME & $\mathrm{T}$ \\
\hline Brassicaceae & $\begin{array}{c}\text { Capsella bursa- } \\
\text { pastoris (L.) Medik. }\end{array}$ & 1 & Yes & Co & $\mathrm{TH}$ \\
\hline Brassicaceae & Sinapis arvensis L. & 2 & & & \\
\hline Caryophyllaceae & $\begin{array}{l}\text { Stellaria media (L.) } \\
\text { Vill. }\end{array}$ & 2 & yes & Co & $\mathrm{TH}$ \\
\hline Chenopodiaceae & $\begin{array}{c}\text { Chenopodium album } \\
\text { L. }\end{array}$ & 16 & yes & Co & $\mathrm{T}$ \\
\hline Convolvulaceae & $\begin{array}{l}\text { Calystegia sepium } \\
\text { (L.) R. Br. }\end{array}$ & 2 & & Co & $\mathrm{H}$ \\
\hline Convolvulaceae & $\begin{array}{c}\text { Convolvulus arvensis } \\
\text { L. }\end{array}$ & 1 & yes & Co & HG \\
\hline Fumariaceae & Fumaria officinalis L. & 12 & yes & $\mathrm{Pt}$ & $\mathrm{T}$ \\
\hline Lamiaceae & $\begin{array}{c}\text { Lamium } \\
\text { amplexicaule } \mathrm{L} .\end{array}$ & 1 & & $\mathrm{Pt}$ & $\mathrm{T}$ \\
\hline Malvaceae & Malva sylvestris L. & 5 & yes & EA & $\mathrm{TH}$ \\
\hline Papaveraceae & Papaver rhoeas L. & 15 & yes & $\mathrm{Pt}$ & $\mathrm{T}$ \\
\hline Papaveraceae & $\begin{array}{c}\text { Glaucium } \\
\text { flavum } \text { Crantz }\end{array}$ & 2 & & & \\
\hline Poaceae & $\begin{array}{l}\text { Aegilops geniculata } \\
\text { Roth }\end{array}$ & 3 & & $\mathrm{Me}$ & $\mathrm{T}$ \\
\hline
\end{tabular}




\begin{tabular}{|c|c|c|c|c|c|}
\hline Poaceae & $\begin{array}{l}\text { Avena barbata Link } \\
\text { in Schrad. }\end{array}$ & 1 & yes & $\mathrm{Me}$ & $\mathrm{T}$ \\
\hline Poaceae & Avena sterilis $\mathrm{L}$. & 1 & & MS & $\mathrm{T}$ \\
\hline Poaceae & Briza maxima $\mathrm{L}$. & 1 & & ST & $\mathrm{T}$ \\
\hline Poaceae & Bromus rigidus Roth & 1 & & ST & $\mathrm{T}$ \\
\hline Poaceae & Bromus tectorum L. & 1 & & $\mathrm{Pt}$ & $\mathrm{T}$ \\
\hline Poaceae & $\begin{array}{l}\text { Cynodon dactylon } \\
\text { (L.) Pers. }\end{array}$ & 2 & yes & Co & $\mathrm{G}$ \\
\hline Poaceae & $\begin{array}{c}\text { Cynosurus echinatus } \\
\text { L. }\end{array}$ & 1 & & $\mathrm{Me}$ & $\mathrm{T}$ \\
\hline Poaceae & $\begin{array}{l}\text { Echinochloa crus- } \\
\text { galli (L.) P. Beauv. }\end{array}$ & 1 & yes & Co & $\mathrm{T}$ \\
\hline Poaceae & $\begin{array}{l}\text { Hordeum murinum } \\
\text { L. }\end{array}$ & 2 & & MS & $\mathrm{T}$ \\
\hline Poaceae & Lagurus ovatus L. & 1 & & $\mathrm{Me}$ & $\mathrm{T}$ \\
\hline Poaceae & Lolium perenne L. & 1 & & ES & $\mathrm{H}$ \\
\hline Poaceae & Melica ciliata $\mathrm{L}$. & 1 & & MS & $\mathrm{H}$ \\
\hline Poaceae & $\begin{array}{c}\text { Piptatherum } \\
\text { miliaceum (L.) Coss. }\end{array}$ & 1 & & $\mathrm{Me}$ & $\mathrm{CH}$ \\
\hline Poaceae & Poa bulbosa L. & 1 & & $\mathrm{Pt}$ & $\mathrm{H}$ \\
\hline Poaceae & $\begin{array}{c}\text { Setaria viridis (L.) P. } \\
\text { Beauv. }\end{array}$ & 1 & & Co & $\mathrm{T}$ \\
\hline Poaceae & $\begin{array}{l}\text { Sorghum halepense } \\
\text { (L.) Pers. }\end{array}$ & 1 & & {$[\mathrm{Co}]$} & G \\
\hline Urticaceae & Urtica dioica $\mathrm{L}$. & 11 & yes & $\mathrm{Co}$ & $\mathrm{H}$ \\
\hline Veronicaceae & $\begin{array}{c}\text { Veronica persica } \\
\text { Poir. in Lam. \& Poir. }\end{array}$ & 1 & & $\begin{array}{l}\text { [W- } \\
\text { As. }]\end{array}$ & $\mathrm{T}$ \\
\hline Zygophyllaceae & Tribulus terrestris L. & 1 & yes & Co & $\mathrm{T}$ \\
\hline
\end{tabular}

*Bk: Balkan, BI: Balkan-Italy, BA: Balkan-Anatolia, BC: Balkan-Central Europe, EM: East Mediterranean, Me: Mediterranean,

MA: Mediterranean-Atlantic, ME: Mediterranean-European, MS: Mediterranean-SW Asian, EA: European-SW Asian, ES: Euro-Siberian, Eu:European, Pt: Paleotemperate, Ct: Circumtemperate, IT: Irano-Turanian, SS: Saharo-Sindian, ST: Subtropical-tropical,

Bo: (Circum-) Boreal, AA:Arctic-Alpine, Co:Cosmopolitan, [trop., subtrop., paleotrop., neotrop., pantrop., N-Am., S-Am., E-As., SE-As., S-Afr., Arab., Arab. NE-Afr., Caucas., Pontic, Europ., Austral.]: Origin of the alien taxa in [tropical, subtropical, paleotropical, neotropical, pantropical, N American, S American, E Asian, SE Asian, S African, Arabian, Arabian NE African, Caucasian, Pontic, European, Australian, unknown, etc., optionally a combination of these].

*** P: Phanerophyte, C: Chamaephyte, H: Hemicryptophyte, G: Geophyte (Cryptophyte), T: Therophyte, A: Aquatic (Dimopoulos 2013, 2016).

\section{Relationships between Plant Species Richness and Environmental Variables}

According to the results of the Principal Component Analysis (PCA), the first two components interpret together $89.0 \%$ of the variance of the relationships between plant species richness and environmental factors (component $1=60.0 \%$, component $2=29 \%$ ). More specifically, it was detected that there is a positive correlation among plant species richness and phosphorus $(\mathrm{P})$, potassium $(\mathrm{K})$, organic matter $(\mathrm{OM})$, temperature $(\mathrm{T})$ and moisture $(\mathrm{M})$ of the soil in the organic cultivation of sage (Figure 2). 


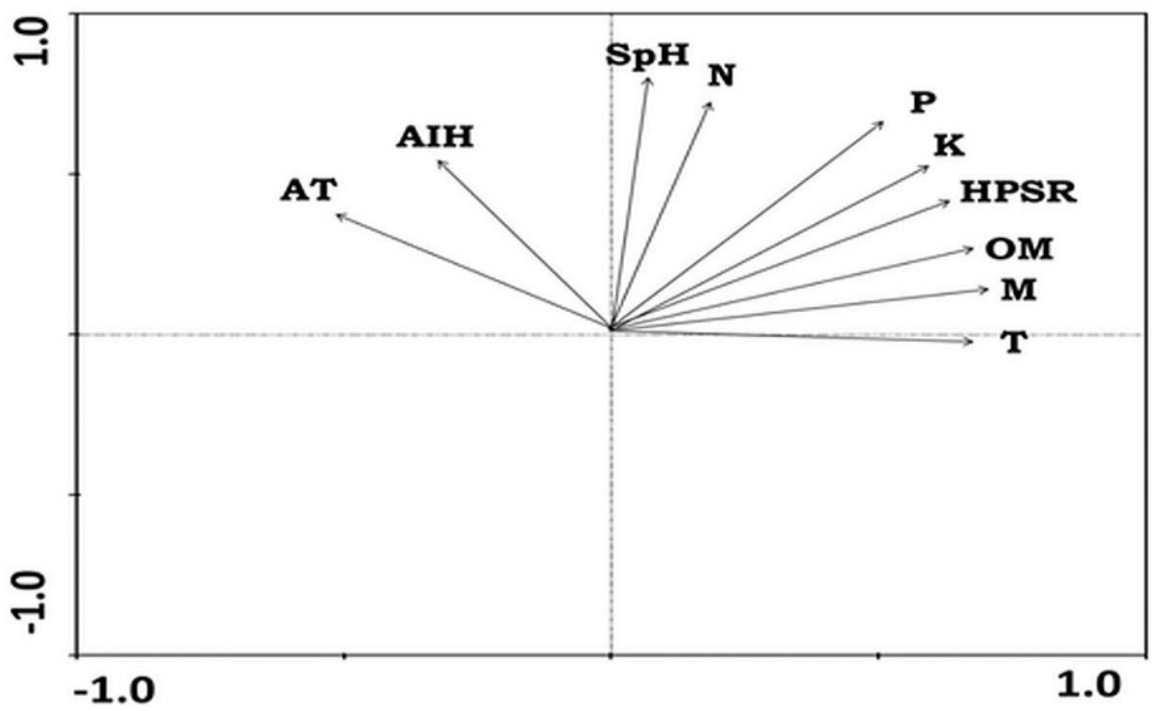

Figure 2. Principal Component Analysis (PCA). (Abbreviations: AT: Air Temperature, AIH: Air Humidity, SpH: Soil pH, N: Nitrogen, P: Phosphorus, K: Potassium, HPSR: Herbaceous Plant Species Richness, OM: Organic matter, M: Moisture, T: Temperature)

Ecology studies focus mostly on the determination of factors controlling the distribution patterns within the plant communities. Several studies on species richness have found a humped curve which has to do with a productivity gradient when productivity is often influenced by the level of an environmental variable. More specifically, organic soil provides important nutrients such as phosphorus and potassium used by plants in large quantities for their growth and survival. Phosphorus is omnipresent in all forms of life being a key element in the physiological and biochemical process. Phosphorus in plants has a major role in photosynthesis, this vital process which converts light energy into a chemical one, necessary for fueling the plants' activities. Potassium also promotes photosynthesis by accelerating the transport of metabolites and by enhancing storage substances. Moreover, it is known to favour protein production, improve the efficiency of nitrogen supplies and its fixation and benefit the efficiency of water management.

All the above could be attributed to the theory based on the model of AlMufti et al (1977) and Grime (1979) ("humped-back curve"). This model has to do with low species richness where the nutrient availability is low and subsequent increase at intermediate levels. Many scientists through their research point out that environmental factos directly affect soil properties albeit in various scales. So, nutrients, soil humus, rainfall and temperature affect the synthesis and plant diversity both in agricultural and natural ecosystems (Peng et al., 2012; Solomou and Sfougaris 2015). 
Another important policy targeting the increase of plant species and their richness focuses on increasing the soil water availability (moisture) and temperature. These two factors affect the growth and overall health of a plant, because root growth (responsible for water and nutrient intake) together with the decomposition of organic matter are linked with the very existence of the plant. The impact of high soil temperature exhibits variations; it is not the same for all plant/genotypes within plant species (Kasper and Bland, 1992). Franklin et al (2013) proved that high soil temperature affects every aspect of growth. The duration/intensity of high soil temperature together with the overall production development really defines the health of the plants involved. Soil temperature is controlled by a number of factors such as air temperature and soil properties (surface-water content- texture). We must also include topographical parameters (altitude-slope- aspect) even the vegetation cover (Liu and Tianxiang, 2011). Soil moisture is another key determinant for many chemical and biological functions, affecting certain mineralization rates and the decomposition of organic matter. In the case of natural ecosystems, climactic conditions have to be taken into consideration, too (humidity-rainfall). All these, together with water and mineral intake (Weih and Karlsson, 2002) are the controllers of plant diversity, distribution and community composition in general (Domisch et al. 2002).

\section{CONCLUSIONS}

Organic sage cultivation promotes every aspect of an ecosystem, including that of plant diversity. It was recorded that there are several plants used as indices for the ideal produce conditions in a biologically active soil system. These plants are: Chenopodium album (index of good soil), Papaver rhoeas (index of nonacidic soil), Fumaria officinalis (index of ventilated-wet soil) and Urtica dioica (index of soil nitrogen) which provide valuable information on the fertility and overall health of the soil. In this way, copious soil analyses are unnecessary and a better selection of soil improvers can be achieved. Another important aspect presented, is that of the medicinal value of these plants, which highlights the urgent need for the conservation and preservation of them; their therapeutic use should not be overlooked and these basic data should be used for further research regarding pharmaceutical studies.

Last but not least, the study investigated the factors affecting herbaceous plant species varieties/richness related to environmental factors. Thus, phosphorus, potassium, organic matter, temperature and moisture, play an important role in organic sage cultivation. This study proves the ecological value of organic sage cultivation and can be used as a tool for the protection of the ecosystem, the wider scientific community the general public during the current economic crisis. Medicinal plants are currently being given their rightful place; so sage may assist future cost/benefit analysis regarding the organized cultivation of the plant in crop rotation schemes in the foreseeable future in Greece and generally in the Mediterranean region. 


\section{ACKNOWLEDGEMENTS}

This work was supported by the Institute of Mediterranean and Forest Ecosystems, Hellenic Agricultural Organization "DEMETER" and Department of Agriculture, Crop Production and Rural Environment, University of Thessaly.

\section{REFERENCES}

Ahnström J. 2002. Ekologiskt Lantbruk Och Biologisk Mångfald: En Litteraturgenomgång [Organic farming and biodiversity: a literature review]. Centre for Sustainable Agriculture, Swedish University of Agricultural Sciences, Uppsala, Sweden [in Swedish].

Al-Mufti MM, Sydes CL, Furness SB, Grime JP, and Band SR. 1977. A quantitative analysis of shoot phenology and dominance in herbaceous vegetation. Journal of Ecology, 65;759-791.

Bengtsson JA, Weibull AC. 2005. The effects of organic agriculture on biodiversity and abundance: a meta-analysis. Journal of Applied Ecology, 42; 261-269

Bogers RJ, Craker LE, and Lange D. 2006. Medicinal and aromatic plants: Agricultural, commercial, ecological, legal, pharmacological and social aspects (Wageningen UR Frontis Series). Netherlands: Springer.

Bradley P. 2006. Sage Leaf. British Herbal Compendium, a handbook of scientific information on widely used plant drugs. Companion to the British Herbal Pharmacopoeia. Bournemouth, 2; 339-344.

Bremner JM, Mulvaney CS. 1982. Nitrogen, in: A.L. Page, R.M. Miller, D.R. Keeney (Eds.). Methods of soil analysis, part 2: Chemical and microbiological properties. Madison, Wisc.: Agron. Soc. of America and Soil Sci. Soc. of America.

Christopoulou-Geoyiannaki M, and Masouras T. 2015. Comparison of Aroma Compounds in Distilled and Extracted Products of Sage (Salvia officinalis L.). Agriculture and Forestry, 61;79-84.

Cordeau S, Reboud X, and Chauvel B. 2010. The relative importance of farmer practices and landscape structure on the weed flora of sown grass strips. Agriculture Ecosystem and Environment, 139; 595-602.

Dimopoulos P, Raus T, Bergmeier E, Constantinidis T, Iatrou G, Kokkini S, Strid A, and Tzanoudakis D. 2016. Vascular plants of Greece: An annotated checklist. Supplement. Willdenowia, 46; 301-347.

Dimopoulos P, Raus T, Bergmeier E, Constantinidis T, Iatrou G, Kokkini S, Strid A, and Tzanoudakis D. 2013. Vascular Plants of Greece: An Annotated Checklist. Berlin, Botanic Garden and Botanical Museum Berlin-Dahlem, Athens, Hellenic Botanical Society.

Domisch T, Leena F, and Tarja L. 2002. Growth, carbohydrate and nutrient allocation of Scots pine seedlings after exposure to simulated low soil temperature in spring. Plant and Soil, 246;75-86.

Fischer C, Flohre A, Clement LW, Batáry P, Weisser WW, Tscharntke T, and Thies C. 2011. Mixed effects of landscape structure and farming practice on bird diversity. Agriculture Ecosystem and Environment, 141; 119-125

Franklin K, Philip W. 2013. Temperature and plant development: John Wiley \& Sons.

Grime JP. 1979. Plant strategies and vegetation processes. Wiley, Chichester, U.K.

http1://www.naturalmedicinalherbs.net/include/searchherb.php?herbsearch=Chenopodiu $\mathrm{m}+$ album $\& \mathrm{x}=8 \& \mathrm{y}=9$ (accessed February 17, 2019).

http2://www.naturalmedicinalherbs.net/include/searchherb.php?herbsearch=Papaver+rhoe as $+\& x=13 \& y=7$ (accessed February 17, 2019).

http3://www.naturalmedicinalherbs.net/include/searchherb.php?herbsearch=Fumaria+offi cinalis $\& \mathrm{x}=3 \& \mathrm{y}=6($ accessed February 19,2019$)$ 
http4://www.naturalmedicinalherbs.net/include/searchherb.php?herbsearch=Urtica+dioica $+\& \mathrm{x}=17 \& \mathrm{y}=8($ accessed February 19,2019$)$

Hyvönen T, Salonen J. 2002. Weed species diversity and community composition in cropping practices at two intensity levels: a six year experiment. Plant Ecology $154 ; 73-81$.

IBM Corp. IBM® ${ }^{\circledR}$ SPSS ${ }^{\circledR}$ Statistics for Windows, Version 23.0.0.0. (2015). Armonk, NY: IBM Corp.

Kasper TC, Bland WL. 1992. Soil temperature and root growth. Soil Science, 154; 290299.

Liu X, Tianxiang L. 2011. Spatiotemporal variability of soil temperature and moisture across two contrasting timberline ecotones in the Sergyemla Mountains, Southeast Tibet. Arctic, Antarctic, and Alpine Research, 43;229- 238

McLean EO. 1982. Soil pH and lime requirement, pp. 199-224, in: A.L. Page et al., (Eds.), Methods of soil analysis. Chemical and microbiological properties. Madison: Agronomy Society of America, Soil Sci. Soc. of America.

Mitsios J, Toulios M, Charoulis A, Gatsios F, and Floras S. 2000. Soil study and soil Chart of the Experimental field of the University of Thessaly in Velestino area. Publications Zymel, Athens (in Greek).

Nelson DW, Sommers LE. 1982. Total carbon, organic carbon and organic matter, pp. 539-579, in: A.L. Page, et al., (Eds.). Methods of soil analysis. Chemical and microbiological properties. Madison: Agronomy Soc. of America, Soil Sci. Soc. of America.

Olsen SR, Sommers LE. 1982. Phosphorus, in: A.L. Page, R.M. Miller, D.R. Keeney (Eds). Methods of soil analysis, part 2: Chemical and microbial properties. Madison, Wisc.: Agronomy Soc. of America and Soil Sci. Soc. of America.

Page AL, Miller HR, and Keeney RD. 1982. Methods of soil analysis, part 2: Chemical and microbiological properties, Madison, Wisc: Agronomy Society of America and Soil Science Society of America.

Peng W, Song T, Zeng F, Wang K, Du H, and Lu S. 2012. Relationships between woody plants and environmental factors in karst mixed evergreen-deciduous broadleaf forest, southwest China. Journal of Food Agriculture and Environment, 10;890896.

Ravlic M, Balicevic R, Nikolic M, and Sarajlic A. 2016. Assessment of allelopathic potential of fennel, rue and sage on weed species hoary cress (Lepidium draba). Notulae Botanicae Horti Agrobotanici Cluj-Napoca, 44; 48-52.

Russo A, Formisano C, Rigano D, Senetore F, Delfine S, Cardile V, Rosselli S, and Bruno M. 2013. Chemical composition and anticancer activity of essential oils of Mediterranean sage (Salvia officinalis L.) grown in different environmental conditions. Food and Toxicology, 55; 42-47.

Solomou AD, Skoufogianni E, and Danalatos NG. 2020. Exploitation of soil properties for controlling herbaceous plant communities in an organic cultivation of lippia citriodora in the mediterranean landscape. Bulgarian Journal of Agricultural Science 26; 79-83.

Solomou AD, Skoufogianni E, Mylonas C, Germani R, and Danalatos NG. 2019. Cultivation and utilization of "Greek mountain tea" (Sideritis spp.): Current knowledge and future challenges. Asian Journal of Agriculture and Biology, 7; 289-299.

Skoufogianni Elpiniki, Solomou A.D., Kamperllari1 F., Nicholaos G. Danalatos. 2017. Ecology, Cultivation, Composition and Utilization of Salvia Officinalis L. In Greece: A Review. Global Advanced Research Journal of Agricultural Science (ISSN: 2315-5094) Vol. 6(12) pp. 449-455, December, 2017. Special Anniversary Review Issue. Available online http://garj.org/garjas/home 
Skoufogianni E, Solomou AD, and Danalatos NG. 2019. Ecology, cultivation and utilization of the aromatic Greek oregano (Origanum vulgare L.): A review. Notulae Botanicae Horti Agrobotanici Cluj-Napoca, 47; 545-552.

Solomou A, Skoufogianni E, and Kamperllari F. 2017. Patterns of Herbaceous Plant Species Richness, Composition and Soil Properties in an Organic Cultivation "Lemon Verbena" and Abandoned Agroecosystems of Greece. Agriculture and Forestry, 63; 35-42.

Solomou A, and Skoufogianni E. 2016. Alpha and Beta Plant Diversity in Multispecies Agroecosystems of Central Greece. Agriculture and Forestry, 62; 19-25.

Solomou A, Martinos K, Skoufogianni E, and Danalatos N. 2016. Medicinal and Aromatic Plants Diversity in Greece and Their Future Prospects: A Review. Agricultural Science 4; 9-20.

Solomou AD, and Sfougaris AI. 2015. Determinants of Woody Plant Species Richness in Abandoned Olive Grove Ecosystems and Maquis of Central Greece. Communications in Soil Science and Plant Analysis, 46; 317-325

Stefanou P, Baloutas D, Katsinikas D, Avraam E, Kyriazopoulos A, Parisi Z, and Arabatzis G. 2015. Cultivation and production of aromatic plants in Greece: present situation, possibilities and prospects, Proceedings of the 8th Panhellenic Rangeland Congress, At Thessaloniki-Greece.

Ter Braak CJF, Smilauer P. 2002. CANOCO reference manual and Canoco Draw for Windows user's guide: Software for canonical community ordination (version 4.5). Ithaca, N.Y.: Microcomputer Power.

Thomas GW. 1982. Exchangeable cations, pp. 159-165, in: A.L. Page, R.M. Miller, D.R. Keeney (Eds.), Methods of soil analysis. Part 2. Chemical and microbiological properties. Second edition. Agronomy Monograph Number 9, Madison, Wisconsin, USA: Agron. Soc. of America, Soil Sci. Soc. of America.

Verma RS, Padalia RC, and Chauhan A. 2015. Harvesting season and plant part dependent variations in the essential oil composition of Salvia officinalis L. grown in northern India. Journal of Herbal Medicine, 5; 165-171.

Weih M, Karlsson PS. 2002. Low winter soil temperature affects summertime nutrient uptake capacity and growth rate of mountain birch seedlings in the subarctic, Swedish lapland. Arctic, Antarctic, and Alpine Research, 34;434-439.

Zar JH. 1999. Biostatistical analysis (Fourth Edition). Upper Saddle River, N.J.: Prentice Hall. 